\title{
The Effect of Joko Widodo's Political Marketing Communication in Instagram on His Image and Reputation in the Eyes of Millennial Generation in Jakarta
}

\author{
http://dx.doi.org/10.25008/jkiski.v5i2.307
}

\author{
Nur Kholisoh ${ }^{1}$, Siti Muslichatul Mahmudah ${ }^{2}$ \\ ${ }^{1,2}$ Department of Communication, Universitas Mercu Buana Jakarta \\ Jl. Meruya Selatan No. 1, Jakarta 11650 - Indonesia \\ *Corresponding author: nur.kholisoh@mercubuana.ac.id
}

\author{
Submitted: September 11, 2020, Revised: November 29, 2020, Accepted: December 25, 2020 \\ Accredited by Kemristekdikti No. 28/E/KPT/2019
}

\begin{abstract}
This research aims to study the effect of Joko Widodo's political marketing communication in Instagram on his image and reputation in the eyes of millennial generation in the 2019 Indonesian Presidential Election. The theory used in this research is the Stimulus Organism Response, Persuasion Message Theory in political communication and theories or concepts of reputation and image. The paradigm used is positivist with a quantitative approach. This research uses a survey method with a questionnaire as a data collection instrument to obtain information from a number of millennials as respondents aged between 19 and 39 years and participating in the 2019 Presidential Election with a total number of around 2,885,000. Determination of sample size uses the Slovin formula with a margin of error of $5 \%$, so the number of samples is 400 people. The sampling technique uses proportional sampling, while the data analysis technique uses path analysis. The results showed that political marketing communication has a direct effect on reputation at $11.9 \%$. The image has a direct effect on reputation at $83.5 \%$, and the indirect effect of marketing communication through image on reputation is $69.97 \%$.
\end{abstract}

Keywords: Marketing communication; instagram; reputation; image; millennial generation

\section{Introduction}

In the 2019 Indonesian Presidential and Vice Presidential Election, according to Firmanzah (2008), political marketing plays an important role that is actualized through marketing strategy as an appropriate way to gain victory in general elections. Marketing in the political world can be used to increase efficiency, effectiveness, ideological transfer and work programs conveyed by candidates to the public. Marketing can also inspire candidates to make work programs based upon the problems faced by the community. The results of marketing can only be achieved if contestants receive wide support from voters. This is also true with Joko Widodo who sought second term in the 2019 presidential election.
According to Hassanudin (2015), one of the marketing units in political communication is using a variety of media in place including new media. New media as a means of conveying messages in mass communication are widely used by individuals, groups and political parties since media can broaden the people's outlook and knowledge of general elections until they are aware to partake in the general elections.

Currently, many political parties use new media as a political communication channel on account of the increasing number of new media users interconnected by the internet. According to Neilsen in Monggilo (2016), in the second quarter of 2015, Indonesia was ranked eighth from 3.2 billion internet users worldwide. Meanwhile, 
Halim (2019) is his study, shows that television and internet-based media become sources mostly used by the public to find political information in the Special Capital Region of Jakarta (DKI Jakarta).

For youths, the internet is a dominant public space. The Indonesian Association of Internet Service Providers (APJII) revealed $16.68 \%$ of millennials aged between 16 and 18 years use the internet to access various kinds of information, while $49.52 \%$ of internet users aged between 19 and 34 years access the internet for information.

According to APJII, $87.13 \%$ of millennials have Facebook, Instagram, Twitter, and YouTube accounts, so that they become a potential group for political parties to grab votes. The number of millennials as young voters continues to increase every general election. In 2010, their number reached 40.7 million. According to the General Elections Commission (KPU), the figure rose to 59.6 million in 2014, and further moved up to 60 million in 2019 across Indonesia.

In view of the potentially large number of young voters to increase votes, many political parties and politicians convey their political messages through new media on the assumption that the millennial generation will accept the political messages more easily through new media than through conventional media.

\section{Theoretical Frameworks}

This research uses Stimulus Organism Response (S-O-R) theory introduced by Hovland, et. al (in Effendy, 2011). According to the S-O-R theory, a change in behavior hinges on the quality of stimulus received by organism. A change in attitude is a learning process made by individuals, where the messages and stimuli are conveyed by a message sender. The stimuli referred to in this research is message in political communication conducted through new media.

The messages are received millennial generation as message recipient (organism). In this case, organism can accept or reject the messages conveyed by message sender. If rejected, the stimuli are less effective to influence the political awareness and participation of millennial generation. If accepted, the stimuli show the millennial generation's attention. This means that the stimuli are effective to influence the political awareness and participation of the millinneal generation. The millennial generation will then process the stimuli they receive, so that they will be prepared to act or take attitude in response to the stimuli received from te political messages in new media.

One of the political marketing models that are widely used in political contestation is Lees-
Marshment Model also known as Comprehensive Political Marketing (CMP) model. CMP was developed by a management expert of Universitas Keele, the United Kingdom, Jennifer LeesMarshment. CMP concentrates attention not merely on the method and strategy of political parties in campaigns but more importantly, on how political parties design their policies acceptable to the market. This model concentrates attention on what political parties do to respond to voters' wish. Political parties use marketing concepts and techniques not only to communicate their products but also to guide them to decide what will be their products and how will they take attitude towards the political market.

There are three characteristics of CMP model, that are: (1) applying marketing approaches to the entire organizational attitude of political parties, not merely limited to campaigns and strategies, (2) integrating political science to the marketing analysis and concept adjusted to tranditional understanding of political p;arties. The marketing concepts of prices, products, places and promotion are adjusted so that they can be applied to the activities of political parties, and (3) PCM highlights its products, namely Oriented Party (POP), Sales Oriented Party (SOP), and Market Oriented Party (MOP).

POP is oriented to products. Political parties or candidates already have policy products and working program and try to make the products acceptable to voters. SOP is oriented to sales. Political parties or candidates already have products. To make the products acceptable to voters, they must be adjusted to the voters' wish. POP is oriented to the market. The products of political parties or candidates in the form of policy, work program should be adjusted to voters' wish. This means that the products should be made based upon the voters' needs.

\section{Instagram as New Media}

According to McQuail (2011), new media is communication media with communication and information technology background. The term new media has been used since the 1960s and covers the exposure of ever-growing and varied communication technology (McQuail, 2011). Lister, M., Dovey, J., Giddings, \& Kelly, K. (2009) explained that new media can mean "a series of broad changes in media production, media distribution and media use".

Kaplan and Haenlein (2010), stated new media covers the emergence of digital, computer, or information and communication technology networks. Today, the internet, as a communication means of new media, becomes needs because it has 
quick access to send or receive data so that human beings can communicate with one another though they stay in different places in the world. Web 2.0 technology-based internet applications has made it possible to create and exchange information based on user-generated content in social media.

Social media is online media, a means that enables its users to communicate and interact, irrespective of physical distance, geographical distance and time. In addition, social media also serves as a means of online social association through the internet. According to Feri Sulianta (2015), types of social media include facebook, twitter, youtube, and instagram.

The research conducted by Dedi Sahputra (2020) and published in the ISKI Journal noted that social media is information media which functions as a means of information exchange movement considered to be the fastest and massive movement that forms a new pattern of social movement, namely functional civil society.

The national survey conducted by the Centre for Strategic and International Studies (CSIS) in 2017 reveals that $81.7 \%$ of millennial generation have facebook accounts, $70.3 \%$ have whatsapp accounts, and 54,7\% have instagram accounts, This study chooses intagram accounts as the focus of this research since instagram application enables users to upload photos and videos to the feed that can be edited using a variety of filters and controlled with tags and location information. Uploads can be shared by the public that have become followers of the account owner.

The research conducted by Atmodjo (2015), shows that youths can easily express something through social media and express a feeling of unease though social media. The internet is like two sides of the same coin in that it has either positive or negative elements. For some of students, the internet can be used as learning media.

Based on the results obtained in Christina's research (2020), that the media literacy skills of the millennial generation include literacy skills related to the ease of accessing the media; proficiency in media analysis; and proficiency in evaluating the media.

Users can explore contents of other users based on tags and locations to see trending contents. Users can also like photos, follow other users and add their contents to enter the veranda.

This study uses an Image concept which in communication language, according to Keith Davis in Yulianita (1999), means "The picture in ourhead". The picture referred to herein means a mental picture containing positive and negative elements. The image, according to Kasali (1999), is "impression arising from the understanding of a reality. The understanding emerges due to information".

According to Zalpha (2016), the public image of a political party is a dimension linking voters to the political party. Self identification with a political party can be said to be the feeling of somebody; a certain political party is his political identity. In other words, somebody identifies himself as a certain political party man, or feels close to a certain political party.

Public image can also be seen from the intermediation of political party and the evaluation of voters group, the extent to which a political party functions as a means to link the interests of voters group to public decisions to be made by the parliament and the government.

The other concept used in this study is reputation, that is a concept in public relations which is difficult to define firmly. Reputation is intangible asset of which existence is difficult to measure and explain because it is not a visible product. After all, the presence of good reputation can strengthen the position of institution when encountering a rival.

This study prioritizes millennial generation as respondents. According to Kupperschmidt (2003), millennial generation is a group of individuals based on similarities in birth year, age, location, and various events in the life of the individual group that has a significant impact on their growth phase.

Howe \& Strauss (1991) divide generations based on similarities in a span of birth time and similarities in historical events. According to Nobel \& Schewe (2003), the basic understanding of generation grouping is a premise that generation is group of individuals influenced by various historical events and cultural phenomena occurring and experienced in their life phase. This means that each generation has different approach, like millennial generation in political communication.

Nowadays, millennial generation has been a hot topic for discussion in the community, from the standpoints of education, technology, moral and culture. William Strauss and Neil Howe (1991) have been widely known as the creator of millennial concept. They created the term in 1987 when children born in 1982 entered pre-school class.

At that time, the media began to call them the group connected to new millennium when they graduate from senior high school in the 2000s. Strauss and Howe (1991) wrote about this group in the book Generations: The History of America's Future Generations, 1584 to 2069 dan Millennials Rising: The Next Great Generation. 
Millennials or known as generation $\mathrm{Y}$, is a group of people born between the 1980s and the 2000s. They are younger generation aged between 17 and 37 years this year. Millennials are considered special because they greatly differ from the previous generation in accessing technology.

Millennial generation has tyoical characteristics: they were born when color television had been invented, handphone and the internet had been widely used so that this generation is very good at using various products of information technology.

In the previous research conducted by Endah Muwarni (2018) and published in the ISKI journal, she highlighted several things since most of Twitter and Instagram users are youths and first-time voters. Therefore, politicians need to consider them to manage the impression they want to build, particularly in packing contents that will potentially increase younger generation's participation in political issues.

Under such context, this study aims to see the effect of Joko Widodo's political marketing communication in the Instagram on his image and reputation in the eyes of millennial generation in the 2019 Presidential Election. Meanwhile, the research hypothesis built to prove the effect is as follows:

$\mathrm{Ha}_{1}$ : There is an effect of political marketing communication in the Instragram on the reputation of Joko Widodo in the eyes of millennial generation;
$\mathrm{Ha}_{2}$ : There is an effect of political marketing communication in the Instragram on the image of Joko Widodo in the eyes of millennial generation;

$\mathrm{Ha}_{3}$ : There is an effect of political marketing communication in the Instagram through image on the reputation of Joko Widodo in the eyes of millennial generation.

\section{Material and Methodology}

This research uses positivist paradigm with quantitative approaches. The method used for this research is a survey method using questionnaires as a data collection instrument to get information from a number of millennials in DKI Jakarta. The millennials that become respondents in this study are considered to represent the millennial generation in DKI Jakarta.

The population in this research is millennials aged between 19 and 39 years and participating in the 2019 Presidential Election and Legislative Election and domiciled in DKI Jakarta. Based on the recapitulation of definitive voter lists (DPT) for the 2019 general elections from the Jakarta Provincial General Elections Commission (KPU) in 2018, the number of voters aged between 19 and 39 years reached 2,885,000, who become population in this research.

To compute the number of samples from the population, the researcher uses Slovin formula:

$n=N /(1+N(e 2)$

$$
\begin{gathered}
\text { Where : } \\
n \text { : Sample } \\
\mathrm{N}: \text { Population } \\
\text { e : Standard error or critical value }
\end{gathered}
$$

Samples are taken with a $95 \%$ confidence level or a $5 \%$ critical value so that sample size is obtained as follows:

$$
\begin{gathered}
\stackrel{n=}{n} \begin{array}{c}
2.885 .000 \\
1+2.885 .000(5 \%)^{2}
\end{array} \\
n=\quad 399.9=400 \text { respondents (rounded up) }
\end{gathered}
$$

Based on the above computation, the number of samples is 400 (rounded up). To obtain the spread of samples in five administrative cities, the following computation is used:

Sample size $=$ Total population $\times$ Population samples 
Based on the computation, the spread of samples as per administrative city territory is as follows:

\begin{tabular}{|l|l|l|}
\hline \multicolumn{1}{|c|}{ City Territory } & \multicolumn{1}{|c|}{ Population } & Total Samples (rounded up) \\
\hline South Jakarta & 605,980 people & 84 people \\
\hline West Jakarta & 629,320 peo ple & 88 people \\
\hline North Jakarta & 605,250 people & 83 people \\
\hline Central Jakarta & 267,360 people & 38 people \\
\hline East Jakarta & 771,058 people & 106 people \\
\hline Seribu Islands & 6,966 people & 1 person \\
\hline
\end{tabular}

The operationalization of variables in this study is as follows:

Table 1. Operationalization of Variables

\begin{tabular}{|c|c|c|}
\hline Variables & Dimension & Indicators \\
\hline \multirow[t]{3}{*}{$\begin{array}{l}\text { Political Marketing } \\
\text { Communication } \\
\text { (Exogen) }\end{array}$} & Product Oriented Party & $\begin{array}{l}\text { - Has a policy } \\
\text { - Has a program } \\
\text { - Tries to be accepted by voters }\end{array}$ \\
\hline & Sales Oriented Party & $\begin{array}{l}\text { - Adjusts a policy to voters' wish } \\
\text { - Adjusts a program to voters' wish }\end{array}$ \\
\hline & Market Oriented Party & $\begin{array}{l}\text { - Policy is adjusted to voters' needs } \\
\text { - Program is adjusted to voters' needs }\end{array}$ \\
\hline \multirow[t]{6}{*}{$\begin{array}{l}\text { Reputation } \\
\text { (Endogen) }\end{array}$} & Emotional Appeal & $\begin{array}{l}\text { - Has a good feeling, } \\
\text { - Has feeling of amazement and } \\
\text { appreciation } \\
\text { - Has confidence }\end{array}$ \\
\hline & Product and Service & $\begin{array}{l}\text { - Stands behind products/services } \\
\text { - Offer high quality products/services } \\
\text { - Devellops innovative products/services } \\
\text { - Offer product/ service that are good value }\end{array}$ \\
\hline & Vision and Leadership & $\begin{array}{l}\text { - Has excellent leadership, } \\
\text { - for the future, } \\
\text { - Recognize/takes advantage of market } \\
\text { opportunities }\end{array}$ \\
\hline & Workplace Environtment & $\begin{array}{l}\text { - a well managed, } \\
\text { - Looks like a good company to work for, } \\
\text { - Looks like has a good employees }\end{array}$ \\
\hline & Financial Performance & $\begin{array}{l}\text { - Record of profitability, } \\
\text { - Look like a low risk invesment, } \\
\text { - Strong prospect for future growth, } \\
\text { - Tends to out performs its competitors } \\
\end{array}$ \\
\hline & Social Responsibility & $\begin{array}{l}\text { - Supported good causes, } \\
\text { - Environtmentally reponsible, } \\
\text { - Treats people well }\end{array}$ \\
\hline \multirow[t]{4}{*}{$\begin{array}{l}\text { Image } \\
\text { (Intervening) }\end{array}$} & Perception & $\begin{array}{l}\text { - Object perceived } \\
\text { - Attention }\end{array}$ \\
\hline & Cognition & $\begin{array}{l}\text { - Heredity } \\
\text { - Environent } \\
\text { - } \text { Maturity } \\
\text { - } \text { Formation } \\
\text { - Interest and Talent } \\
\text { - } \text { Freedom } \\
\end{array}$ \\
\hline & Motivation & $\begin{array}{l}\text { - Encourages } \\
\text { - Directs } \\
\text { - Supports }\end{array}$ \\
\hline & Attitude & $\begin{array}{l}\text { - } \text { Awareness } \\
\text { - } \text { Feeling } \\
\text { - } \text { Behavior }\end{array}$ \\
\hline
\end{tabular}


This study uses a quantitatve data analysis technique with path analysis. According to Kriyantono (2012), in a quantitative research there are several stages that must be done by a researcher in analyzing data, namely Data Coding, Data
Entering, Data, Data Output, and Data Analyzing. This research is in parametric group so that data analysis techninque used is path analysis with the following model :

- Path model

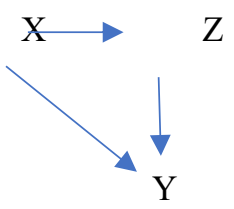

- Structure similarities

Structure $1: Z=\rho_{\mathrm{ZX}} \mathrm{X}+\varepsilon_{1}$

Structure $2: \mathrm{Y}=\rho_{\mathrm{Yx}} \mathrm{X}+\rho_{\mathrm{Yz}} \mathrm{Z}+\varepsilon_{2}$

$\mathrm{X}=$ Variable of politic message in social media (Independent)

$\mathrm{Z}=$ Variable of political awareness (Intervening)

$\mathrm{Y}=$ Variable of political participation (Dependent)

$$
\begin{gathered}
\rho=\text { Path coefficient } \\
\varepsilon=\text { Error }
\end{gathered}
$$

\section{Result and Discusssion}

Path analysis using path mode:

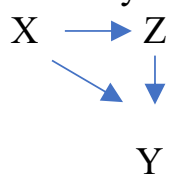

Structure similarities

Structure $1: Z=\rho_{\mathrm{Y} 1 \mathrm{x}} \mathrm{X}+\varepsilon_{1}$

Structure $2: \mathrm{Y}=\rho_{\mathrm{Y} 2 \mathrm{x}} \mathrm{X}+\rho_{\mathrm{Y} 2 \mathrm{y} 1} \mathrm{Y}_{1}+\varepsilon_{2}$

$\mathrm{Y}$

Result

- Structure 1 :

- $\mathrm{Z}=0.838$

$\varepsilon_{1}=\sqrt{1-R^{2}}=\sqrt{1-0.703}=\sqrt{0.297}=0.54$

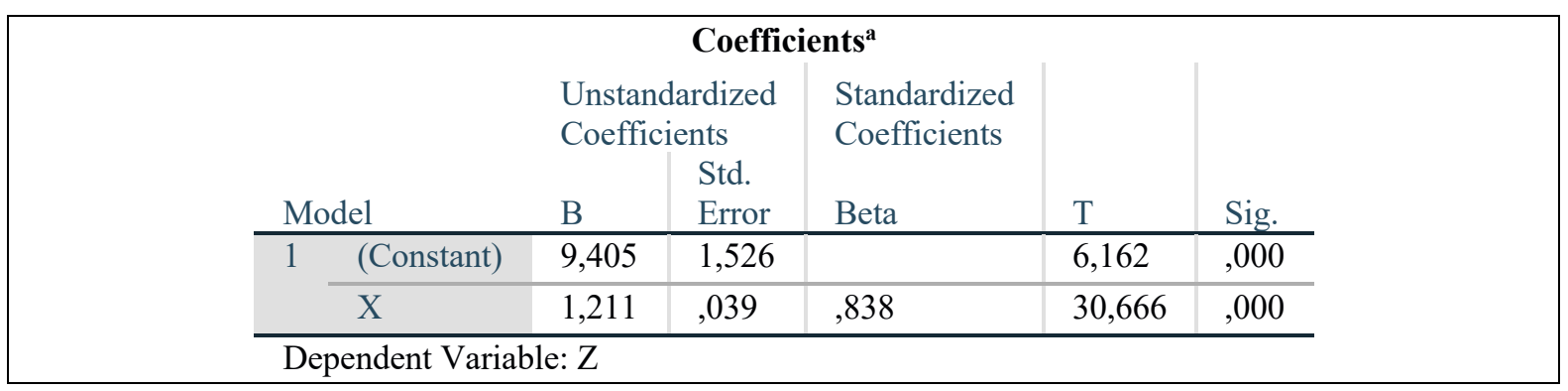

\begin{tabular}{|c|c|c|c|c|c|c|}
\hline & & \multicolumn{3}{|c|}{ Coefficients $^{\mathrm{a}}$} & \multirow[b]{3}{*}{$\mathrm{t}$} & \multirow[b]{3}{*}{ Sig. } \\
\hline & & \multicolumn{2}{|c|}{$\begin{array}{l}\text { Unstandardized } \\
\text { Coefficients }\end{array}$} & \multirow{2}{*}{$\begin{array}{l}\text { Standardized } \\
\text { Coefficients } \\
\text { Beta }\end{array}$} & & \\
\hline \multicolumn{2}{|c|}{ Model } & B & $\begin{array}{l}\text { Std. } \\
\text { Error }\end{array}$ & & & \\
\hline 1 & (Constant) & $-7,944$ & 1,481 & & $-5,365$ & , 000 \\
\hline & $\mathrm{X}$ & ,247 &, 067 &, 119 & 3,680 &, 000 \\
\hline & Z & 1,203 & 046 & 835 & 25,900 & ,000 \\
\hline
\end{tabular}

$$
\begin{array}{cc}
\bullet \quad & \text { Structure } 2: \\
\cdot & \mathrm{Y}=0.877+0.835 \\
\varepsilon_{1}=\sqrt{1-R^{2}}=\sqrt{1-0.877}=\sqrt{0.123}=0.35
\end{array}
$$




\section{Dependent Variable: $\mathrm{Y}$}

- Structure Similarities :

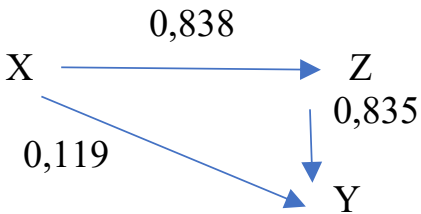

Based on the result of path analysis test, it is found

\section{Path Model I: Effect of $X-Z$}

Based on the test of the effect of $\mathrm{X}$ on $\mathrm{Z}$, a significant value of 0,000 or less than 0.05 is found. This means that $\mathrm{Ha}$ is accepted with a constant value of 1.211, which means a positive effect. The effect size is 0.838 or $83.8 \%$, which means that the political marketing communication of Joko Widodo has an affect on his image at $83.8 \%$.

\section{Path Model II : Effect of XZ - Y}

Based on the test of the effect of $\mathrm{X}$ on $\mathrm{Y}$, a significant value of 0.000 or less than 0.05 is obtained. This means that $\mathrm{Ha}$ is accepted with a constant value of 0.247 , which means a positive effect.

Based on the test of the effect of $\mathrm{Z}$ on $\mathrm{Y}$, a significant value of 0.000 or less than 0.05 is obtained. This means that $\mathrm{Ha}$ is accepted with a constant value of 1.203 , which means a positive effect.

The combined effect of $\mathrm{X}$ and $\mathrm{Z}$ on $\mathrm{Y}$ is 0.877 or $87.7 \%$. This means that the political marketing communication and image of Joko Widodo has an effect on his reputatkion at $87.7 \%$.

Based on the test of path analysis model II, direct and indirect effects are obtained as follows:

Direct effect: The direct effect of variable X on $\mathrm{Y}$ is $11.9 \%$, while the direct effect of variable $\mathrm{Z}$ on $\mathrm{Y}$ is $83.5 \%$.

Indirect effect. The indirect effect of variable $\mathrm{X}$ through variable $\mathrm{Z}$ on variable $\mathrm{Y}$ is $0.838 \times 0.835$ $=0.6997=69.97 \%$. This means that the indirect effect of political marketing communication through image variable on the reputation of Joko Widodo is $69.97 \%$.

The total effect of variable $\mathrm{X}$ on $\mathrm{Y}$ is $11.9 \%$ $+69.97 \%=81.87 \%$. This means that the total effect of political marketing communication on the reputation of Joko Widodo is $81.87 \%$.

Based on the result of data analysis, it is found that the political marketing communication of Joko Widodo in social media Instagram has a direct and positive effect on his reputation though the effect is not significant, only at $11.9 \%$. This is different from the direct effect of image on his reputation, which has a positive and significant effect, at $83.5 \%$. This suggests that the image built by Joko Widodo during his first term of office as the President of the Republic of Indonesia has been strongly instilled in the community so that it has more significant effect than the political marketing communication he made in the 2019 Presidential and Vice Presidential Election.

Meanwhile, there is an indirect effect of political marketing communication through image on the reputation of Joko Widodo, with a positive and quite significant effect, at $69.97 \%$. This effect is inseparable from the role of image formed in the community towards Joko Widodo. The total effect of political marketing communication on the reputation of Joko Widodo is 81.87 .

This means that overall, the political marketing communication done by Joko Widodo, either directly or indirectly, has a positive and quite significant effect on his reputation in the 2019 Presidential Election. After all, the direct effect of image on his reputation is still larger and more significant than the total effect of political marketing communication on his reputation in the 2019 Presidential Election.

\section{Conclusion}

Based on the result of data analysis in this research, it could be concluded that the political marketing communication done in the Instagram has a mutual affect on the image and reputation of Joko Widodo in the eyes of millennial generation. Meanwhile, the result of this research shows that the direct effect of political marketing technology in social media instagram only $11.9 \%$ affects the reputation of Joko Widodo. Therefore, it is necessary to intensify the effort to convey political messages as one of the models of political marketing communication done by Joko Widodo in social media, particularly instagram.

\section{References}

Andreas, K. M., Haenlein M. (2010). Users of the World, Unite! The Challenges and 
Opportunities of Social Media. Business Horizons, 53(1), 61.

Atmodjo, J. T. (2015). Media Massa dan Ruang Publik: Analisis Perilaku Penggunaan Sosial Media dan Kemampuan Remaja dalam Menulis. Jurnal Visi Komunikasi, Fikom Universitas Mercu Buana, Jakarta, 14(2), 223-238

Effendy, O.U. (2011). Ilmu Komunikasi. Teori dan Praktek, Bandung: Rosda.

Firmanzah. (2008). Marketing Politik Antara Pemahaman dan Realitas Edisi Kedua. Jakarta: Yayasan Obor Indonesia

Halim, Umar., Jauhari, KD. (2019), Pengaruh Terpaan Media terhadap Partisipasi Politik dalam Pilkada DKI Jakarta 2017, Jurnal Aspikom, 4(1), 45-59.

Hasanuddin, H, Badjido, MY, Hardi, Y (2015), Peran Media Massa Dalam Peningkatan Partisipasi Pemilih Pemula Pada PILKADA 2013 Di Kecamatan Tempe Kabupaten Wajo, Jurnal Otoritas, 5(1), 37-51.

Kasali, R. (1999). Membidik Pasar Indonesia: Segmentasi, Targeting, Positioning. Jakarta: Penerbit Gramedia.

Kriyantono, R. (2012). Teknik Praktis Riset Komunikasi Cetakan ke-6. Jakarta: Kencana Prenada Media.

Kupperschmidt, B. R. (2000). Multigeneration Employees: Strategies for Effective Management; The Health Care Manager, 19(1), 65 .

Lister, M., Dovey, J., Giddings, S., Grant, I., \& Kelly, K. (2009). New Media: A Critical Introduction. USA : Routledge.

McQuail, D. (2011). Mass Communication Theory (Translated) Jakarta: Salemba Humanika.

Monggilo, Z. M. (2016). Kajian Literatur Tipologi Perilaku Berinternet Generasi Muda Indonesia. Jurnal Dirjen Risbang Kemenristekdikti. 13(1), 31-48.

Muwarni, E. (2018). The Impression Management Strategy of the Candidates of Governor-Vice Governor of DKI Jakarta on Social Media. Jurnal Komunikasi Ikatan Sarjana Komunikasi Indonesia, 3(02),113-121

Noble, S. M., \& Schewe, C. D. (2003). Cohort segmentation: An exploration of its validity. Mississippi: The University of Mississippi.

Saputra, D., Indra M., Taufik W., Waridah. (2020). Social Media and Civil Society in the Governor's Election of North Sumatera 2018. Jurnal Komunikasi Ikatan Sarjana Komunikasi Indonesia, 5 (1), 10-17.

Strauss, William; Howe, Neil (1991). Generations: The History of America's Future, 1584 to 2069. Harper Perennial.
Sulianta, F (2015). Keajaiban Sosial Media, Jakarta : Elex Media Komputindo.

Yulianita, N. (1999). Dasar-Dasar Public Relations. Bandung: Fakultas Ilmu Komunikasi Universitas Islam Bandung.

Zalpha, Y. (2016). Analisis Konflik pada Munas Golkar 2014. Jurnal Intizar, 22(1). 